First record of a nonpaleotropical intejocerid cephalopod from Darriwilian (Middle Ordovician) strata of central Spain

\title{
Kröger, Björn
}

2020-03

pÿKröger , B \& Gutierrez-Marco , J C 2020 , ' First record of a nonpaleotropical intejocerid cephalopod from Darriwilian (Middle Ordovician) strata of central Spain ' , Journal of Paleontology , vol. 94 , no. 2 , 0022336019000660 , pp. 273-278 . https://doi.org/10.1017/jpa.2019.66

http://hdl.handle.net/10138/312007

https://doi.org/10.1017/jpa.2019.66

cc_by

acceptedVersion

Downloaded from Helda, University of Helsinki institutional repository.

This is an electronic reprint of the original article.

This reprint may differ from the original in pagination and typographic detail.

Please cite the original version. 


\section{First record of a non-paleotropical intejocerid cephalopod from}

\section{Darriwilian (Middle Ordovician) strata of central Spain}

4 Björn Kröger1 and Juan Carlos Gutiérrez-Marco2

5

61 Finnish Museum of Natural History, PO Box 44, Fi-00014 University of Helsinki, Finland,

7 <bjorn. kroger@helsinki.fi>

8 2 Instituto de Geociencias (CSIC, UCM), and Departamento de Geodinámica, Estratigrafía y

9 Paleontología, Facultad CC. Geológicas, José Antonio Novais 12, 28040 Madrid, Spain.

$10<$ jcgrapto@ucm.es>

12 Running Header: peri-Gondwana intejocerid

14 Abstract.- The order Intejocerida is an enigmatic, short lived cephalopod taxon, known

15 previously only from Early-Middle Ordovician beds of Siberia and the USA. Here, we

16 report a new genus, Cabaneroceras n. gen., and a new species of C. aznari n. sp. from

17 Middle Ordovician strata of central Spain. This finding widens the paleogeographic range of

18 the order toward high-paleolatitudinal areas of peri-Gondwana. A curved conch,

19 characteristic for the new genus, was previously unknown from members of the Intejocerida.

21 UUID: http://zoobank.org/21f0a09c-5265-4d29-824b-6b105d36b791 


\section{Introduction}

26 Intejocerids are a unique group of cephalopods, previously known only from Siberia (Balashov

27 1960, 1962, 1968) and North America (Flower, 1964, 1968; VanCamp Gil, 1988). The most

28 conspicuous characters of intejocerids are their long septal necks, and their large siphuncles,

29 which are filled with heavy lamellar deposits and which form a coral-like radial pattern in cross

30 section. Like other cephalopods with long septal necks and heavy endosiphuncular deposits,

31 intejocerids were relatively large for their time with conch diameters reaching more than 100

$32 \mathrm{~mm}$. The isolated, several decimeter long steinkerns of the specimens described herein occur

33 exclusively and in relative high abundance at a single locality in the northern Ciudad Real

34 province where they are found as the weathered residue of the soft mudstone of the Navas de

35 Estena Formation. The steinkerns are often superficially eroded and parts of the phragmocone,

36 such as septa and outer shell are not preserved. This obstructed the correct identification of these

37 remains as cephalopods, which were originally interpreted as remains of hexactinellid

38 dictyospongids (Gutiérrez-Marco et al., 2013, p. 596, fig. 4c, 2015a, p. 130, fig. 20A). Here, we

39 identify and describe these fossils for the first time in detail.

\section{Geological setting}

43 The examined material comes from three nearby localities in the central part of the Mounts of

44 Toledo area, central Spain, two of them situated within the Cabañeros National Park ('Los

45 Medianiles' and 'Navaldelchorro', see Gutiérrez-Marco et al., 2013, 2015a) and the third

46 immediately adjacent to same ('Cuesta de Valderuelo' section, see Reyes-Abril et al., 2010; 
47 Gutiérrez-Marco and Sá, 2017) (Fig.1). This area belongs to the southern part of the Central

48 Iberian Zone of the Iberian Massif, where large outcrops of Paleozoic fossiliferous rocks have

49 been known since the middle half of the XIX century, including early reports and illustrations of

50 Middle Ordovician cephalopods both from the Portuguese (Sharpe, 1849) and Spanish parts

51 (Verneuil and Barrande, 1855).

52 All studied specimens come from a relatively narrow (5-45 m) stratigraphic interval of

53 fossiliferous mudstones located at the lower third of the Navas de Estena Formation. The

54 formation is a thick (up to $800 \mathrm{~m}$ ) Darriwilian succession of massive dark mudstones and

55 siltstones, partly with noduliferous horizons. The Navas de Estena Formation (Fm)

56 stratigraphically overlies the Lower Ordovician sandstone group comprising the Armorican

57 Quartzite (Floian age) and the transitional Marjaliza beds (Floian-Dapingian ages).

58 From north to south, the fossiliferous localities in the Navas de Estena Fm are as follows:

60 Locality 'Navaldelchorro'.-About 10,000 m to the south of Los Navalucillos (province of

61 Toledo), east of Posturero' house on the left bank of the La Calanchera stream (lat. 39 34' 28'

62 N, long. $4^{\circ} 39^{\prime} 13.7^{\prime \prime}$ W). From this locality (Fig. 1.2a) came a single limonitic siphuncle

63 (MGM-81960), from mudstone beds c. $100 \mathrm{~m}$ above the base of the Navas de Estena Formation.

65 Locality 'Cuesta de Valderuelo'.-_Located c. 5,600 m to the SE from Navas de Estena, province 66 of Ciudad Real (lat. $39^{\circ} 27^{\prime} 33^{\prime \prime} \mathrm{N}$, long. $\left.4^{\circ} 28^{\prime} 31^{\prime \prime} \mathrm{W}\right)$. This locality corresponds to the bed NE-

67 IIIA of the section (Reyes-Abril et al., 2010), from which some brachiopods (Reyes-Abril et al., 68 2010) and ichnofossils (Gutiérrez-Marco and Sá, 2017) were described and illustrated. The

69 locality (Fig. 1.2b) is about $120-135 \mathrm{~m}$ above the base of the Navas de Estena Formation, in the 
70 southwestern flank of the Navas de Estena syncline. A single siphuncle preserved in shale was

71 found at Cuesta de Valderuelo (MGM-81970).

72

73 Locality 'Los Medianiles'.-About 8,700 $\mathrm{m}$ to the ENE of Horcajo de los Montes, province of

74 Ciudad Real, in the northern bank of the La Chorrera stream south of Sierra de Valdefuertes (lat.

$7539^{\circ} 21^{\prime} 42,2^{\prime \prime} \mathrm{N}$, long. 4 $33^{\prime} 41^{\prime \prime} \mathrm{W}$ ). From this locality (Fig. 1.2c) we have recovered about 90

76 fragments of isolated steinkerns of intejocerid siphuncles. Only few specimens of this collection

77 occurred strictly in situ, ca. 80-85 m above the base of the Navas de Estena Formation. The

78 majority of specimens have been collected on a labor field which gently dips south from the

79 narrow outcropping area in the northern flank of La Chorrera Syncline.

80

81 All three localities contain an assemblage of trilobites, brachiopods, mollusks, ostracods and

82 echinoderms, detailed by Gutiérrez-Marco et al. (2013, 2015a) for assemblages from Cabañeros

83 National Park (see also: Reyes-Abril et al. 2010; Gutiérrez-Marco and Sá, 2017) for the Cuesta

84 de Valderuelo section. The occurrence of the graptolite Didymograptus artus Elles et Wood, plus

85 some trilobites and brachiopods of regional biochronological significance indicate an early

86 Oretanian age to the assemblage according with the Bohemo-Iberian regional scale (Gutiérrez-

87 Marco et al., 2015b, 2017), equivalent to an early mid Darriwilian age at the global

88 chronostratigraphy (Bergström et al., 2009).

89

90 Materials

91 
92 The available material consists of isolated steinkerns of siphuncles, partly with impressions of

93 septal necks as moulds within the sediment. The steinkerns consist of massive limonite and

94 limonitic mudstone. No original calcareous material is preserved. Preserved parts of septa and

95 septal necks are silicified. Internal characters of the siphuncles can be traced along pattern of

96 differences in the compactness of the limonite. The cross-sections of the specimens are often

97 slightly diagenetically deformed, which is indicated by the similarly deformed endosiphuncular

98 lamellae. Imprints of bryozoan epizoans occur on the silicified shelly surface of the septal necks

99 and on the surface of the steinkern itself (Figs 2.8, 3.2) (specimen MGM-8181O).

100

101 Repositories and institutional abbreviations. - The material described herein is deposited at the

102 Museo Geominero of Madrid (prefixed numbers MGM) which belongs to the Instituto Geológico

103 y Minero de España / IGME (Spanish Geological Survey).

104

105 Systematic paleontology

106

Order Intejocerida Balashov, 1960

107

Family Padunoceratidae Balashov, 1960

108

Genus Cabaneroceras new genus

109

110 Type species.—Cabaneroceras aznari n. sp., by monotypy.

111

112 Diagnosis.-As for the type species by monotypy.

113

114 Occurrence.-Mounts of Toledo, Navas de Estena Formation, central Spain. 
116 Etymology.-The name refers to the Cabañeros National Park in Spain. All currently known

117 specimens of this genus are from this territory or its immediate surroundings (Valderuelo

118 section).

120 Remarks. - The placement of the new genus within the Padunoceratidae is justified by the 121 occurrence of branching, irregularly shaped lamellar endosiphuncular deposits and the

122 holochoanitic septal necks. Cabaneroceras n. gen. differs from other Intejocerids in having a

123 curved conch, a relatively large angle of expansion and relatively shallow concave siphuncular

124 segments. The endosiphuncular lamellae of Cabaneroceras n. gen. are relatively widely spaced, 125 similar to Evencoceras, from which they differ in forming an irregularly spaced ventral 126 endosiphotube.

131 Holotype.-MGM-8183O (Figs 2.1, 2.5, 2.6, 4.4), Navas de Estena Formation, about $100 \mathrm{~m}$ 132 above the base. Lower mid Darriwilian, Didymograptus artus graptolite zone, 'Los Medianiles' 133 site in the northern flank of the La Chorrera syncline, northeast of Horcajo de los Montes, 134 province of Ciudad Real, central Spain.

136 Diagnosis. - Slightly curved brevicones with marginal siphuncle. Siphuncle at concave margin 137 of conch curvature with slightly compressed or circular cross-section with angle of expansion of 
138 c. $8-12^{\circ}$. Ventral margin of siphuncle slightly flattened. Siphuncle diameter c. three to four times

139 that of septal distance. Siphuncular segments slightly concave. Septal necks holochoanitic.

140 Endosiphuncular deposits longitudinally subdivided into c. 25 irregularly spaced radially

141 arranged lamellae separated by narrow, folded blades as interspaces. Lamellae laterally

142 downcurved toward the ventral side forming an endosiphuncular tube with an irregularly

143 compressed semicircular shape in cross section at ventral side of siphuncle.

145 Occurrence.-As for genus, by monotypy.

147 Description.-The holotype is a fragment of a siphuncle, slightly diagenetically laterally

148 compressed with a dorso-ventral diameter of 46-73 mm, a width of 38-60 mm at a length of 135

$149 \mathrm{~mm}$, expanding with an angle of $11.5^{\circ}$ dorso-ventrally. The siphuncle is slightly curved with the

150 ventral side less curved than the dorsal side. Traces of the septa and septal necks are visible on

151 the steinkern only on the dorsal side of the holotype indicating a slightly concave shape of the

152 siphuncular segments and an at least holochoanitic length of the septal necks that ranges over the

153 entire height of chamber. The former position of the septa is visible around the surface of the

154 holotype as rounded ridges. These ridges are oblique toward the growth axis with an angle that is

155 c. $20^{\circ}$ from the angle perpendicular to the growth axis and slopes toward the dorsal

156 (antisiphuncular) side of the conch. In places where the steinkern exposes the inner surface of

157 siphuncular deposits (which is the outer surface of the siphuncle), a number of c. 25 lamellae are

158 visible as broad bands divided by thin $(<1 \mathrm{~mm})$ longitudinal grooves. In cross-section, these

159 lamellae are visible, reaching into a depth of up to $20 \mathrm{~mm}$ of the siphuncle, where they are

160 radially arranged and irregularly folded leaving a central space or tube filled with massive 
161 limonite. The central tube is eccentrically positioned within the siphuncle with a ventral contact

162 to the siphuncular wall and irregularly compressed, with semicircular cross-section.

163 Specimen MGM-8184O (Fig. 2.4) is a part of a steinkern of a siphuncle with a maximum

164 diameter of $71 \mathrm{~mm}$; it has a slightly compressed cross section with particularly well preserved

165 holochoanitic septal necks; at its ventral side it is in a contact to the outer shell, which in its best-

166 preserved parts smooth. Details of potential ornamentation are probably not visible due to

167 preservation.

168

169 Etymology.-The name was given in honour of Alejandro Aznar, the owner of the private

170 property of the type locality, supporter of the 11th International Symposium on the Ordovician

171 System, Spain, 2011 and producer of the fine Rioja wine "Marqués de Riscal".

172

173 Materials. - Seventeen paratype specimens (MGM-8180O - MGM-8189O, MGM-8191O -

174 MGM-8195O, MGM-81980, and MGM-81990) were available for closer examination.

175 Fourteen additional, less valuable or more incomplete specimens, were deposited in the same

176 collection MGM-8196O - MGM-8197O, MGM-8200O - MGM-8206O, and MGM-8225O -

177 MGM-8230O.

178

179 Remarks.-The material of Cabaneroceras aznari n. sp., described above, consists exclusively

180 of fragments of siphuncles. Many of the specimens are also diagenetically slightly deformed.

181 This fragmentary preservation constraints the diagnosis of this new species to the preserved

182 internal characters. However, the erection of a new species and genus is justified, because the 
183 known internal features are unique (see discussion of Cabaneroceras $\mathrm{n}$. gen.) and unknown in

184 this combination from any other padunoceratid cephalopod.

\section{Discussion}

188 Little can be said about the taphonomy and depositional history of the material. The now

189 limonitic mineralogy of the steinkerns probably represents a primary deposition and burying

190 under deoxidized conditions with pyrite $(\mathrm{FeS})$ as replacement of organic rich spaces, and later

191 oxidation and dissolution of the calcareous deposits. Alternatively, massive pyrite may have

192 preferentially replaced the shelly material rich in in organics (e.g. nacre), while carbonate poor in

193 organics may be have been replaced by crystalline pyrite (pers. comm. D. Evans). The local

194 presence of bryozoan epizoans, which covered parts of already broken septa and outer surfaces

195 of the septal necks is evidence of a relatively complex depositional history with potential

196 secondary reworking.

197 The massive limonitic parts of the siphuncles are interpreted by us as originally organic rich

198 shelly material, and in contrast, the less massive, more porous limonitic spaces are interpreted as

199 representing areas originally filled with porous calcareous endosiphuncular deposits. This results

200 in a reconstruction of a pattern with a number of radially arranged lamellae and elongated

201 endoconic cells or compartments that where divided by folded interspaces or endosiphoblades

202 (sensu Flower, 1964, see Fig. 4), a reconstruction which is consistent with siphuncular features

203 of better-preserved material of intejocerids, specifically with Evencoceras Balashov, 1960

204 (Balashov, 1960, pl. 28, fig 1; VanCamp, Gil 1988, fig. 14. 6). The siphuncles described herein

205 differ from all other known intejocerids in having a wider angle of expansion, and in being 
206 slightly curved, which justifies the erection of a new genus and probably would be adequate to

207 suggest a new family if more complete material would be available.

208

209 Conclusions

210

211 Our interpretation and systematic classification of the cephalopod siphuncles collected from the

212 Navas de Estena Formation has two main consequences: (1) The known paleogeographic range

213 of the Intejocerida now widens from restricted to low paleolatitude Siberia and Laurentia toward

214 high latitude peri-Gondwana; (2) the known morphological diversity of the Intejocerida widens

215 significantly from originally restricted to slender orthoconic forms, to now also including slightly

216 curved brevicones. Notably, distinct groups of curved brevicones are known also from other

217 predominantly hemi-holochoantic higher cephalopod taxa, such as the Piloceratidae of the

218 Bisonocerida (comp. Evans and King 2012) and Cyrtendoceratidae of the Endocerida (Teichert

219 1964).

220 The intejocerids reported herein also add to the known diversity of Ordovician cephalopods

221 from the Iberian Peninsula. Currently, this incudes member of the Ascoceridae, Ellesmerocerida,

222 Endocerida, Orthocerida, Lituitida, and Tarphycerida (see: Babin and Gutiérrez-Marco, 1992; Sá

223 and Gutiérrez-Marco, 2009 for previous compilation). With the exception of two tarphycerid

224 species, most of the previously published taxa are based on poorly preserved material occurring

225 as incomplete moulds and casts in siliceous mudstones and sandstones. The absence of critical

226 internal structures in many of these specimens does not allow for a taxonomic identification at

227 genus or species level and many taxa are in need of a revision. Hopefully, the recent reappraisal

228 of early Paleozoic peri-Gondwanan cephalopod faunas from elsewhere (e. g. Kröger et al., 2012; 
229 Evans et al., 2013, 2015; Bogolepova et al., 2014; Niko and Sone, 2014, 2015; Aubrechtová,

230 2015; Cichowolski et al., 2015, 2018; Ghavidel-Syooki et al., 2015; Rolet and Plusquellec, 2016;

231 Aubrechtová and Turek, 2018; Manda and Turek, 2018; Ebbestad et al., 2019; Fang et al., 2019)

232 will stimulate future research on the Iberian cephalopods.

233

\section{Acknowledgments}

235

236 This research was initiated with a grant of the Spanish Autonomous Organism on National Parks

237 (Ref. 052/2009, years 2010-2013) and is a contribution to the projects CGL2017-87631-P of the

238 Spanish Ministry of Science, Innovation and Universities, and IGCP project 653 (IUGS-

239 UNESCO). We thank David H. Evans (Peterborough, UK) and Martina Aubrechtová (Prague,

240 Czech Republic) for their careful and constructive reviews. JCG-M wish to express his gratitude

241 to the authorities of the Cabañeros National Park and especially the owners of the Los

242 Medianiles locality, the family AznarOriol, for permission given for the field work and the

243 facilities received. Carlos Alonso (Universidad Complutense de Madrid, Spain) photographed

244 the specimens.

245

\section{References}

248 Aubrechtová, M., 2015, A revision of the Ordovician cephalopod Bactrites sandbergeri

249 Barrande: Systematic position and palaeobiogeography of Bactroceras: Geobios, v. 48, p.

$250 \quad 193-211$. 
Aubrechtová, M. and Turek, V., 2018, Lituitid cephalopods from the Middle Ordovician of Bohemia and their paleobiogeographic affinities: Bulletin of Geosciences, v. 93, p. 401417.

Babin, C. and Gutiérrez-Marco, J.C., 1992, Intéret paléobiogeographique de la présence du genre Trocholites (Cephalopoda, Nautiloidea) dans le Dobrotivá (Llandeilo) inférieur d'Espagne: Neues Jahrbuch für Geologie und Paläontologie Monatshefte, v. 1992, p. 519-541.

Balashov, E.G., 1960, Novye ordovikskie nautiloidei SSSR [New Ordovician nautiloids of the USSR]: Novye Vidy Drevnikh Rastennyi i Besposvonochnykh SSSR, v. 2, p. 123-137. [in Russian]

Balashov, E.G., 1962, Nautiloidei ordovika sibirskoi platformy [Nautiloids of the Ordovician of the Siberian Platform]: Izdatel'stvo Leningradskogo Universiteta, 205 p. [in Russian]

Balashov, E.G., 1968, Endoceratoidei ordovika SSSR [Ordovician Endoceratoidea of the USSR]: Izdatel'stvo Leningradskogo Universiteta, 170 p. [in Russian]

Bergström, S.M., Chen, X., Gutiérrez-Marco, J.C. and Dronov, A.V., 2009, The new chronostratigraphic classification of the Ordovician System and its relations to major regional series and stages and $\delta 13 \mathrm{C}$ chemostratigraphy: Lethaia, v. 42, p. 97-107.

Bogolepova, O. K., Kröger, B., Falahatgar, M. and Javidan, M., 2014, Middle Ordovician cephalopods from the Abarsaj area, northern Iran: GFF, v. 136, p. 34-37.

Cichowolski, M., Waisfeld, B.G., Vaccari, N.E. and Marengo, L., 2015, The nautiloid Family Eothinoceratidae from the Floian of the Central Andean Basin (NW Argentina and South Bolivia): Geological Journal, v. 50, p. 764-782.

Cichowolski, M., Uriz, N.J., Alfaro, M.B. and Galeano Inchausti, J.C., 2018, Ascocerid cephalopods from the Hirnantian? - Llandovery stages of the southern Paraná Basin 
(Paraguay, South America, first record from high paleolatitudes: Journal of Paleontology, v. 93(1), p. 1-11.

276

277

278

279

280

281

282

283

284

285

286

287

288

289

290

291

292

293

294

Ebbestad, J.O.R., Polechová, M., Kröger, B. and Gutiérrez-Marco, J.C., 2019, Late Ordovician molluscs of eastern Anti-Atlas, Morocco, in Hunter, A.W., Álvaro, J.J., Lefebvre, B., van Roy, P. and Zamora, S., eds., The Great Ordovician Biodiversification Event: Insights from the Tafilalt Biota, Morocco. The Geological Society, London, Special Publication, v. 485, doi: 10. 1144/SP485. 9.

Evans, D.H. and King, A.H., 2012, Resolving polyphyly within the Endocerida: The Bisonocerida nov., a new order of early Palaeozoic nautiloids: Geobios, v. 45, p. 19-28.

Evans, D.H., Ghobadi Pour, M. and Popov, L.E., 2013, Review of Early to Mid Ordovician orthoconic cephalopods from Iran: Bulletin of Geosciences, v. 88, p. 21-44.

Evans, D.H., Ghobadi Pour, M., Popov, L.E. and Jahangir, H., 2015, An early Silurian (Aeronian) cephalopod fauna from Kopet-Dagh, north-eastern Iran: including the earliest records of nonOrthocerid cephalopods from the Silurian of Northern Gondwana: Bulletin of Geosciences, v. 90, p. 479-507.

Fang, X., Burrett, C., Li, W., Zhang, Y., Zhang, Y., Chen, T. and Wu, X., 2019, Dynamic variation of Middle to Late Ordovician cephalopod provincialism in the northeastern peri-Gondwana region and its implications: Palaeogeography, Palaeoclimatology, Palaeoecology, v. 521, p. 127-137.

Flower, R.H., 1964, Nautiloid shell morphology: New Mexico Bureau of Mines and Mineral Resources Memoir, v. 13, p. 1-79. 
Flower, R.H., 1968, Part I. The first great expansion of the actinoceroids. Part II. Some additional Whiterock cephalopods: New Mexico Bureau of Mines and Mineral Resources Memoir, v. 19, p. 1-120.

Ghavidel-Syooki, M., Evans, D.H., Ghobadi Pour, M., Popov, L.E., Álvaro, J.J., Rakhmonov, U., Klishevich, I.A. and Ehsani, M.H., 2015, Late Ordovician cephalopods, tentaculitides, machaeridians and echinoderms from Kuh-e Faraghan, High Zagros, Iran: Alcheringa, v. 39, p. 530-549.

Gutiérrez-Marco, J.C. and Sá, A.A., 2017, Primer registro del icnogénero Phycodes en el Ordovícico Medio de los Montes de Toledo (Zona Centroibérica, España): Boletín de la Real Sociedad Española de Historia Natural, Sección Geológica, v. 110 (for 2016), p. 4348.

Gutiérrez-Marco, J.C., Rábano, I., Sá, A.A., García-Bellido, D.C. and Sarmiento, G.N., 2013, Patrimonio paleontológico del Ordovícico Medio del Parque Nacional de Cabañeros (Castilla-La Mancha), in Vegas, J., Salazar, A., Díaz-Martínez, E. and Marchán, C., eds., Patrimonio geológico, un recurso para el desarrollo. Cuadernos del Museo Geominero, v. 15 , p. 591-599.

Gutiérrez-Marco, J.C., Rábano, I., Sá, A.A., Baeza Chico, E., Sarmiento, G.N., Herranz Araújo, P. and San José Lancha, M.A. de., 2015a, Geodiversidad e itinerarios geológicos en el Parque Nacional de Cabañeros [Geodiversity and geological routes in the Cabañeros National Park], in Amengual, P. and Asensio, B., eds., Proyectos de investigación en parques nacionales: 2010-2013. Organismo Autónomo Parques Nacionales, Serie investigación en la red, v. 7, p. 105-142. 
317 Gutiérrez-Marco, J.C., Sá, A.A., Rábano, I., Sarmiento, G.N., García-Bellido, D.C., Bernárdez,

318 E., Lorenzo, S., Villas, E., Jiménez-Sánchez, A., Colmenar, J. and Zamora, S., 2015b,

319 Iberian Ordovician and its international correlation: Stratigraphy, v. 12(3-4), p. 257-263.

320 Gutiérrez-Marco, J.C., Sá, A.A., García-Bellido, D.C. and Rábano, I., 2017, The Bohemo-Iberian

321 regional chronostratigraphic scale for the Ordovician System and palaeontological

322 correlations within South Gondwana: Lethaia, v. 50(2), p. 258-295.

323 Kröger, B. and Lefebvre, B., 2012, Palaeogeography and palaeoecology of early Floian (Early

324 Ordovician) cephalopods from the Upper Fezouata Formation, Anti-Atlas, Morocco:

$325 \quad$ Fossil Record, v. 15, p. 61-75.

326 Manda, S. and Turek, V., 2018, Silurian tarphycerid Discoceras (Cephalopoda, Nautiloidea, systematics, embryonic development and paleoecology: Journal of Paleontology, v. 92, p.

Niko, S. and Sone, M., 2014, Actinocerid cephalopods from the Ordovician of Myanmar, and $412-431$. their paleobiogeographic implications for northern Gondwana: Paleontological Research,

334 Reyes-Abril, J., Villas, E. and Gutiérrez-Marco, J.C., 2010, Orthid brachiopods from the Middle v. 18, p. 94-104.

Niko, S. and Sone, M., 2015, Gondwanan nautiloid cephalopods from the Ordovician of Myanmar: Paleontological Research, v. 19, p. 288-294.

337 Rolet, J. and Plusquellec, Y., 2016, Découverte d'un nautiloïde cyrtocône dans les grès ordoviciens de Bréhec (Massif Armoricain): Bulletin de la Société Géologique et Minéralogique de Bretagne [D], v. 14, p. 3-14. 
340 Sá, A.A. and Gutiérrez-Marco, J.C., 2009, Cefalópodos del Ordovícico Medio de la Formación 341 Valongo, norte de Portugal: Geogaceta, v. 47, p. 9-12.

342 Sharpe, D., 1849, On the geology of the neighbourhood of Oporto, including the Silurian coal 343 and slates of Valongo: Quarterly Journal of the Geological Society, 5, p. 142-153.

344 Teichert, C., 1964, Endoceratoidea, in Moore, R.C., ed., Treatise on Invertebrate Palaeontology, 345 Part K, Mollusca 3. Geological Society of America and the University of Kansas Press, $346 \quad$ Boulder, Colorado, p. K160-K189.

347 Vancamp Gil, A., 1988, Whiterock (lower Middle Ordovician) cephalopod fauna from the Ibex 348 area, Millard County, western Utah: New Mexico Bureau of Mines and Mineral Resources Memoir, v. 44, p. 27-41.

50 Verneuil, E. de and Barrande, J., 1855, Descriptions des fossiles trouvés dans les terrains silurien 351 et dévonien d'Almaden, d'une partie de la Sierra Morena et des montagnes de Tolède:

352 Bulletin de la Société Géologique de France [2e série], v. 12, p. 964-1025. 
Figures and Figure Captions

357 Figure 1. Details of fossil localities and stratigraphy of the occurrences of Cabaneroceras aznari

n. sp., Middle Ordovician, central Spain. (1) General location of the studied area in the Iberian

359 Peninsula (arrowed). Grey area corresponds to the Neoproterozoic basement and Paleozoic rocks

360 affected by the Variscan Orogeny (Iberian Massif). (2) Geological sketch map of a part of the

361 central Mounts of Toledo region showing the position of the localities yielding Cabaneroceras

362 aznari n. gen, n. sp. (type locality in c). (3) Stratigraphic log of a part of the Navas de Estena

363 Formation with the range of the new taxon.

365 Figure 2. Siphuncular fragments of Cabaneroceras aznari n. sp., from Navas de Estena

366 Formation, Middle Ordovician, central Spain: (1) holotype, MGM-8183O, adapical view. (2)

367 specimen MGM-8182O, adapical view. (3) specimen MGM-8184O, adapical view. (4) specimen

368 MGM-8184O, dorsal view. (5) holotype, ventral view. (6) holotype, lateral view. (7) MGM-

369 81860, lateral view. (8) specimen MGM-8181O, ventral view, note horizontal traces of

370 bryozoan overgrowth (see details in Fig. 2b). (9) specimen MGM-8198O, lateral view. (10)

371 specimen MGM-8187O, lateral view. Scale bars $=10 \mathrm{~mm}$, for specimens $\mathbf{1}-\mathbf{8}$ and $\mathbf{9}-\mathbf{1 0}$,

372 respectively. All the specimens where whitened with $\mathrm{MgO}$ before photography.

374 Figure. 3. Details of siphuncular fragments of Cabaneroceras aznari n. sp., from Navas de 375 Estena Formation, Middle Ordovician, central Spain. (1) Longitudinal cross section of steinkern 376 of siphuncular fragment of Cabaneroceras aznari n. sp., specimen MGM-8199O. Dark area is 
377 massive limonite and probably originally was calcareous endosiphuncular deposit. (2) Detail of

378 traces of bryozoan epizoans on specimen MGM-81810 (marked with arrow). Scale bars $=10$

$379 \mathrm{~mm}$. Specimen in $\mathbf{2}$ was whitened with $\mathrm{MgO}$ before photography.

380

381 Figure 4. Camera lucida drawings of cross section view of siphuncle steinkerns of

382 Cabaneroceras aznari n. sp. from Navas de Estena Formation, Middle Ordovician, central Spain.

383 The radial structures are interpreted here as either interspaces between folded siphuncles, or as

384 endosiphoblades (sensu Flower, 1964). All figured specimens are arranged in a position with

385 assumed ventral side down. Note the different orientation and grade of diagenetic compression,

386 which reflects the original position in the sediment: (1) specimen MGM-8188O. (2) specimen

387 MGM-8189O. (3) specimen MGM-8182O. (4) holotype, specimen MGM-8183O. (5) Specimen

388 MGM-8180O. Scale bar $=10 \mathrm{~mm}$.

389 


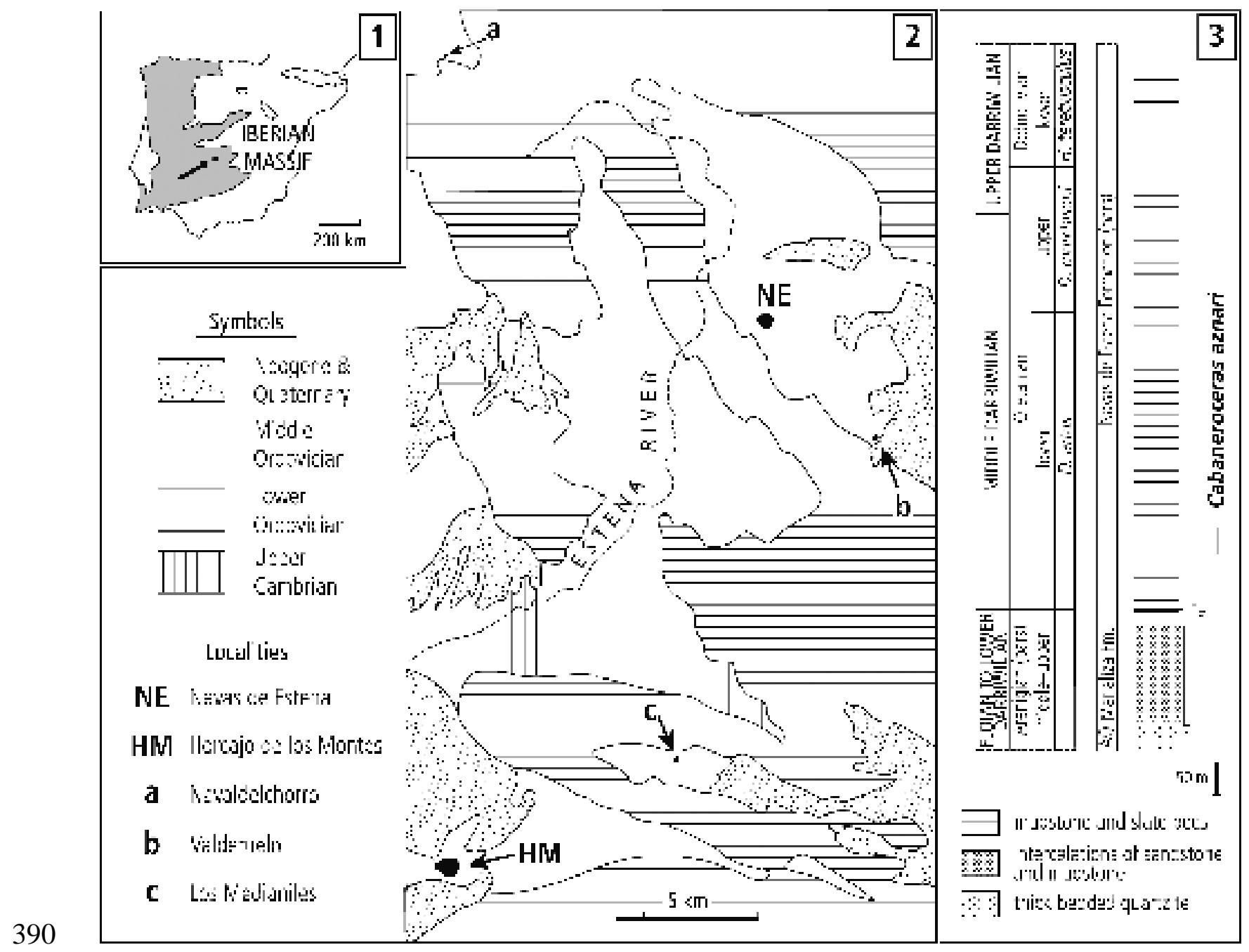



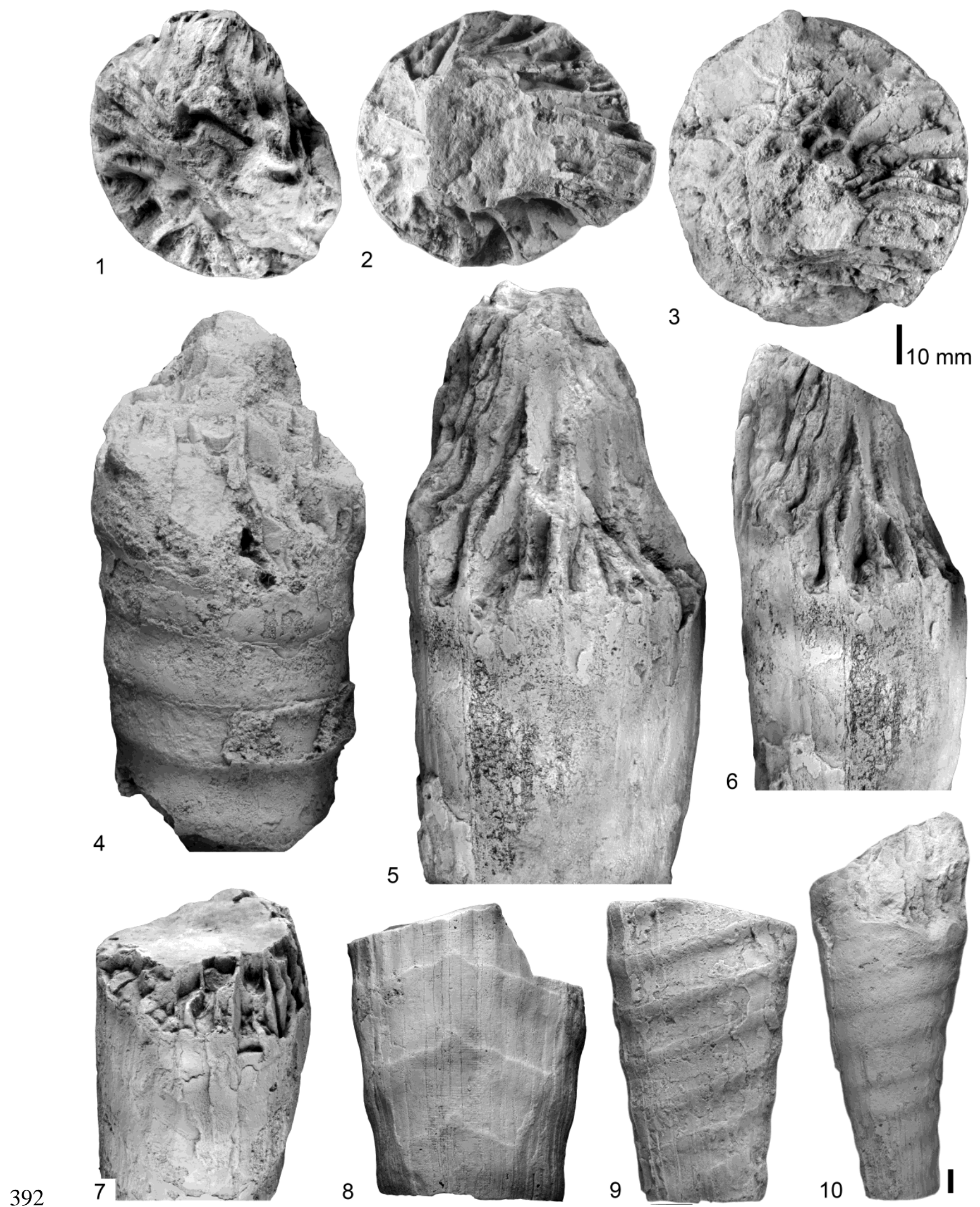

393 


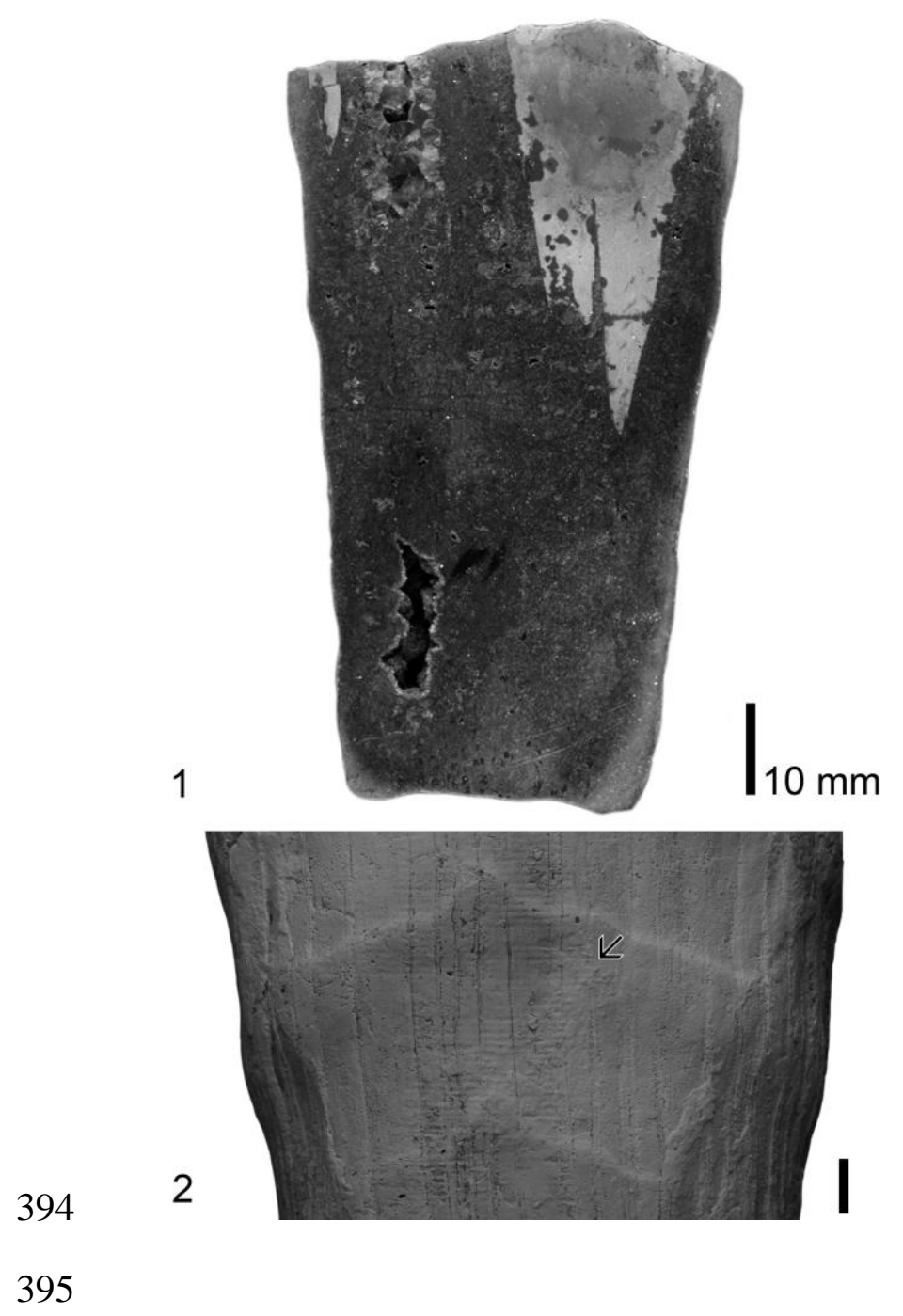




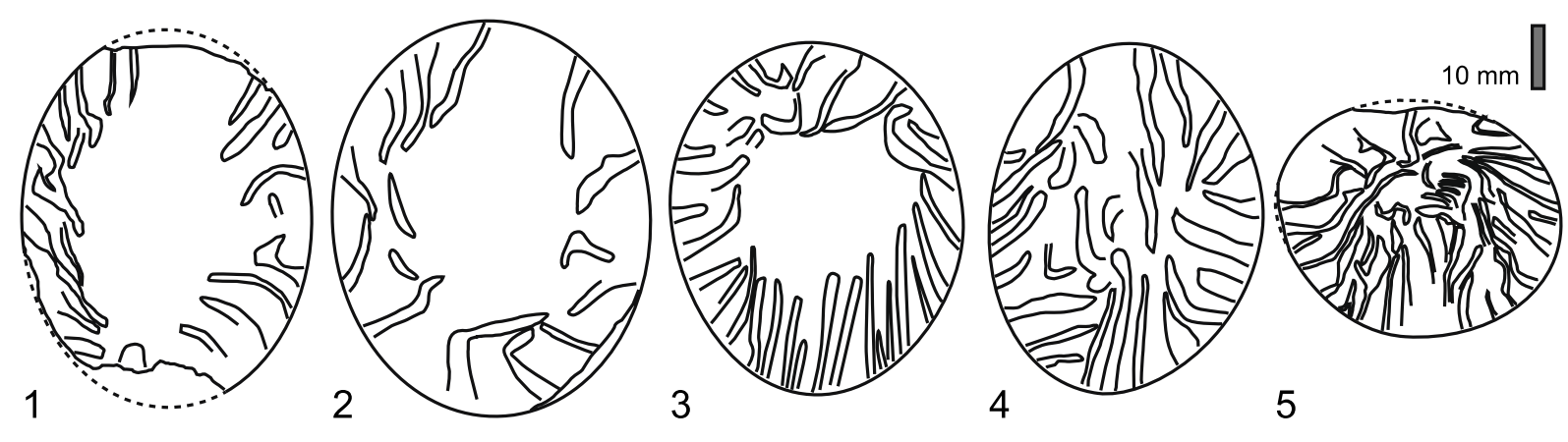

